\title{
Mimic Model: A Tool to Estimate the Shadow Economy
}

\author{
Brunela Trebicka, (PhD Candidate)
}

University "Aleksander Moisiu”, Durres, Albania

\section{Doi:10.5901/ajis.2014.v3n6p295}

\begin{abstract}
Formal economy affects the Shadow economy. This is the reason why the study of shadow economy has attracted a lot of attention of academics and policy makers in recent years. Often, multiple indicators multiple causes (MIMIC) models is applied to time series data to estimate the size and development of the shadow economy for a particular site. This model gives us information about the relationship between cause and indicator variables and a latent variable, here the shadow economy, from covariance structures. Like most macroeconomic variables do not satisfy stationary, long run information is lost when employing first differences. Perhaps, this shortcoming is rooted in the lack of a suitable MIMIC model which considers cointegration among the variables. This paper presents the MIMIC model as an econometric model and then shows how these model coefficients are calculated. The paper also presents the connection that exists between the formal and the shadow economy. Using this model we will be demonstrating that this approach allows the applicant to obtain accurate estimates regarding the size of shadow economy.
\end{abstract}

Keywords: model, shadow economy, unemployment, growth rate

\section{Introduction}

Shadow or hidden economy, sometimes also titled informal or underground economy is defined by (Hart 2008) as a set of economic activities that takes place outside the framework of bureaucratic public and private sector establishments. Another paper by (Ihrig and Moe 2004) defines it as a sector which produces legal goods, but does not comply with government regulations.

Additionally, (Frey and Pommerehne 1984), (Loayza 1996), (Johnson, Kaufmann, and Shleifer 1997), (Johnson, Kaufmann, and Zoido-Lobaton 1998), (Fleming, Roman, and Farrell 2000), (Fleming, Roman, and Farrell 2000), (Friedrich Schneider and Enste 2000), (F. G. Schneider and Enste 2002), (Dell'Anno and Schneider 2004), (Friedrich Schneider 2005) provide or use similar definitions and descriptions among many others. Even though informality is a widespread phenomenon and poses serious social, economic, cultural and political challenges across the world, many issues about its nature and consequences still remain largely under-explored or unresolved.

It is not easy to define and measure the Shadow Economy. And because of this, shadow Economy has got the attention of academics over the world. The academics have been working in creating methods that record the hidden, shadow economic activities. The most common use method includes hidden economic activities that contribute to the official growth national income. ${ }^{1}$ But (Feige 1990) said that tax evasion is only a part of the hidden (shadow) economy. Several other studies, including (Friedrich Schneider and Enste 2000) and (Dreher and Schneider 2010) came to the conclusion that in some countries the shadow economy reaches and even passes $70 \%$ of GDP and the developing countries are leading this.

There are many existing studies in the literature that examine the effects of the shadow economy. These studies suggest that the presence of the shadow economy affects both the level of fiscal policy and its cycling (Çiçek and Elgin 2011). The presence of shadow economy effects also the provision of social security (Friedrich Schneider and Enste 2000), monetary base (Tanzi 1983) the fair income distribution (Hatipoglu and Ozbek 2011) the business cycle (Elgin 2012), and total factor productivity (D'Erasmo and Moscoso Boedo 2012). The increased number of papers shows that there is a high attention to economic analysis of the shadow economy.

Despite the development of various methods, the lack in literature databases makes the shadow economy subject to powerful policy analysis. As mentioned above, by its definition estimating the size of the shadow economy is difficult

${ }^{1}$ An analytical discussion of the various definitions can be found in Schneider and Enste (2000). 
and daunting. Nevertheless, various approaches and methodologies have been suggested and to some extent used in the literature to come up with estimates. (Friedrich Schneider 2005) and more recently (Orsi, Raggi, and Turino 2012) provide an excellent survey and comparison of different ways of estimating the shadow economy size. They differ in various dimensions but they are all based on the use of different econometric methods. To measure the size and development of the shadow economy three different types of methods are most widely used. These are direct approaches, indirect approaches and the MIMIC approach.

In this study, we will rely on MIMIC (Multiple Indicators and Multiple Causes) method to evaluate the size of the shadow economy. MIMIC stands for "Multiple Indicators Multiple Causes" and it is a special case of the general LISREL model.

The method has its origins in the literature of factor analysis of psychometrics, while its exposure to the economy is in models of (Goldberger 1972) and (Zellner 1970). In the first application of MIMIC method for estimation of the gray economy, (Frey and Weck-Hanneman 1984) reviewed the data collected from 17 OECD countries. The idea was developed by (Aigner, Schneider, and Ghosh 1988), who made some adjustments in the dynamic model MIMIC ( or DYMIMIC ) and the method was applied in the United States. Later, (Giles 1999) modified further the method. The modification included time series and particularly the unit root and with this modified method evaluates the shadow economy of New Zealand.

The evaluation with MIMIC method it's attractive in this context. The idea is to represent the output (or income) of the shadow economy as a latent variable or index that has caused noticeable effects, but that cannot be measured directly.

Use of MIMIC modeling has its shortcomings. (Helberger and Knepel 1988) show that the first results of Frey and WECK-Hannemann are unstable in the case of minor changes to the data in the period and the group of countries studied. They also argue that the lists of indicator variables are unconvincing for the purpose.

\section{MIMIC and Econometric Models}

MIMIC model consists of two parts, the structural equation (as shown on (1)) and the measurement equation system (as shown with (2). The structural model examines the relationships between latent variable $(\eta)$ and the causes $(X q)$ and the measurement model links indicators (Xp) and hidden variable ( $\eta$ ). In the MIMIC model, the shadow economy is the latent variable $(\eta)$ and is linearly determined, subject to a disturbance $\zeta$ by a set of observable exogenous causes as:

$\eta=\gamma_{1} x_{1}+\gamma_{2} x_{2}+\ldots \ldots .+\gamma_{q} x_{q}+\zeta$

Latent variable $\eta$ linearly determines, subject to a disturbances $\varepsilon_{1}, \varepsilon_{2}, \ldots \ldots ., \varepsilon_{p}$, the set of observable indicators as $\mathrm{y}_{1}, \mathrm{y}_{2}, \ldots \ldots . ., \mathrm{yp}_{\mathrm{p}}:$

$\left\{\begin{array}{l}y_{1}=\lambda_{1} \eta+\varepsilon_{1} \\ y_{2}=\lambda_{2} \eta+\varepsilon_{2} \\ y p=\lambda p \eta+\varepsilon p\end{array}\right.$

Structural disturbance $\zeta$ and errors $\varepsilon$ are normal distributed, independent and the expectation of the variables are zero. This assumption is crucial to ensure the quality of results ( $F$ Schneider and Dell'Anno 2003)

$x^{\prime}=\left(x_{1}, x_{2}, \ldots, x_{q}\right)$ observable exogenous causes

$\mathrm{y}^{\prime}=\left(\mathrm{y}_{1}, \mathrm{y}_{2}, \ldots, \mathrm{y}_{\mathrm{q}}\right)$ structural parameters in the structural model

$y^{\prime}=\left(y_{1}, y_{2}, \ldots, y_{p}\right)$ observable endogenous indicators

$\lambda^{\prime}=\left(\lambda_{1}, \lambda_{2}, \ldots, \lambda_{p}\right)$ structural parameters in the measurement model

$\varepsilon^{\prime}=\left(\varepsilon_{1}, \varepsilon_{2}, \ldots, \varepsilon_{p}\right)$ measurement errors

$U^{\prime}=\left(U_{1}, U_{2}, \ldots, U_{p}\right)$ standard deviations of the measurement errors

We can rewrite equations (1) and (2) as:

$\eta t=\gamma^{\prime} x_{t}+\zeta_{t}$

$\mathrm{yt}=\lambda \eta_{\mathrm{t}}+\varepsilon_{\mathrm{t}}$

$E\left(\zeta \varepsilon^{\prime}\right)=0$ and $E\left(\zeta^{2}\right)=\sigma^{2}$ and $E\left(\varepsilon \varepsilon^{\prime}\right)=\theta^{2}$.

Here, $\theta(\operatorname{pxp})$ is the diagonal matrix with $\mathrm{u}$, shown on its diagonal. We can write the reduced form of the function of the observable variables as; $y=\lambda\left(\gamma^{\prime} x+\zeta\right)+\varepsilon=\Pi^{\prime} x+v$

So; $\Pi=\gamma \lambda^{\prime}$ and $v=\lambda \zeta+\varepsilon$ Expressing the model in terms of covariance's shows us

$\Sigma=\left(\begin{array}{cc}\operatorname{Var}\left(\mathbf{y}_{\mathbf{t}}\right) & \operatorname{Cov}\left(\mathbf{y}_{\mathbf{t}} \cdot \mathbf{x}_{\mathbf{t}}\right. \\ \operatorname{Cov}\left(\left.\mathbf{x}\right|_{\mathbf{t}} \cdot \mathbf{y}_{\mathbf{t}}\right) & \operatorname{Var}\left(\mathbf{x}_{\mathbf{t}}\right.\end{array}\right)=\mathbf{E}\left(\left[\frac{y_{\mathbf{t}}}{\mathrm{x}_{\mathrm{t}}}\right]\left[\frac{\mathrm{y}_{\mathbf{t}}}{\mathrm{x}_{\mathrm{t}}}\right]{ }^{\prime}\right) \mid$

So the model's covariance matrix gives 


$$
\Sigma=\left(\begin{array}{cc}
\lambda\left(\boldsymbol{\gamma}^{\prime} \boldsymbol{\Phi} \boldsymbol{\gamma}+\boldsymbol{\Psi}\right)+\boldsymbol{\Theta}_{\varepsilon} & \lambda \boldsymbol{\gamma}^{\prime} \boldsymbol{\Phi} \\
\boldsymbol{\Phi} \boldsymbol{\gamma} \lambda^{\prime} & \boldsymbol{\Phi}
\end{array}\right) \mid
$$

$\Sigma$ is a function of parameters. $\lambda, \gamma$ and the covariances contained in $\phi, \theta \varepsilon$ and $\psi$. The latent variable is not observable so, its size is unknown. Therefore the model's parameters must be estimated by using the links between the variances of the observed variables and the covariances. The purpose of the procedure is to find the values of the parameters and covariances that produce an estimate for $\Sigma$

The interaction over a given period of time between the causes $X q(q=1,2,3, \ldots, 6)$, and the size of the shadow economy and its indicators $Y q(q=1,2)$ is shown in following Figure 1.
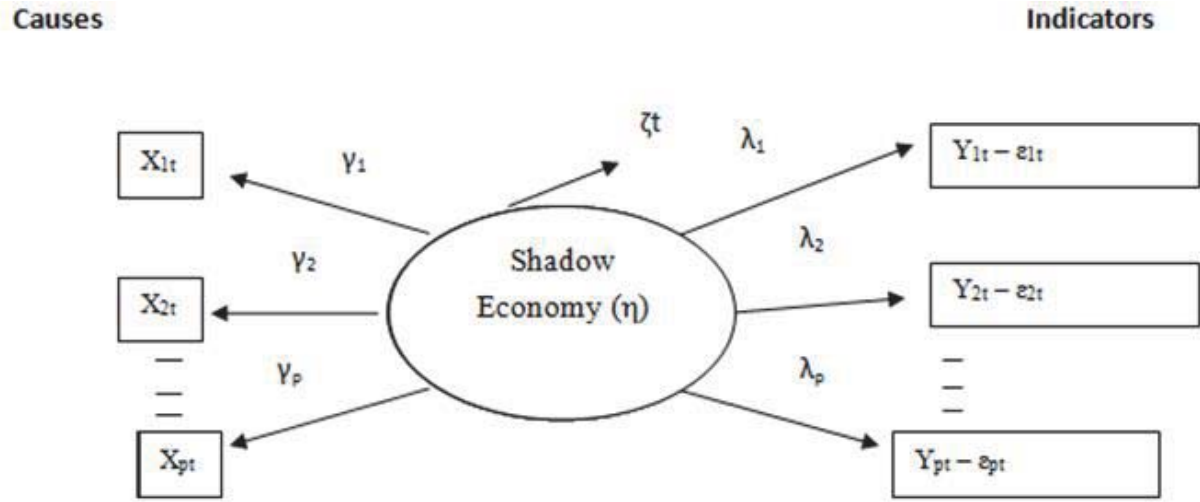

Figure 1. General Structure of a MIMIC model

We use an analytical representation of the most general specification, six determinants, a latent variable and two indicators, represented in the figure, and subsequent changes are produced, excluding the variables that are not statistically significant, in order to try to optimize the model.

\section{Causes $\mathbf{X}_{t}\left(\mathbf{X}_{1}, \mathbf{X}_{2} \mathbf{X}_{6 .}\right)$}

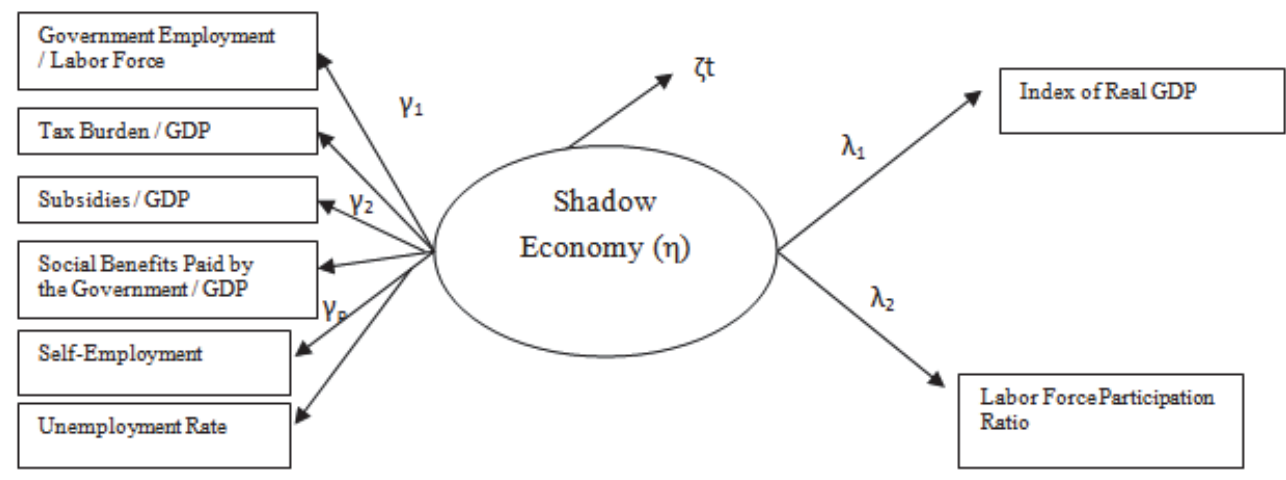

Figure 2. General Structure of a MIMIC model

\section{Estimation of model coefficient}

We use the software Eviews7 to estimate the coefficients by maximum likelihood. We use the same unit of measurement (percentage), the coefficients, $\gamma_{1}$ to $\gamma_{6}$, are directly compared, and the weight of each one explains the dynamics of the Shadow Economy.

As shown in figure 1, we start the Model MIMIC 6-1-2 (six causes, a latent variable and two indicators). We did eliminate the coefficients of the statistically not significant variables in order to optimize the model, and as a result we came up with the MIMIC 2-1-2.

To eliminate the non-stationary of the time series, we transformed the variables in their first differences. 
The estimation results show that the main causes of the Shadow Economy in one country, among those included in the model, are the Unemployment Rate and the Subsidies granted to Enterprises.

Table 1

\begin{tabular}{|c|c|c|c|c|c|c|}
\hline & $\begin{array}{c}\text { Government employment } \\
\text { / labor force }\end{array}$ & $\begin{array}{c}\text { Tax Burden / } \\
\text { GDP }\end{array}$ & $\begin{array}{c}\text { Subsidies / } \\
\text { GDP }\end{array}$ & $\begin{array}{c}\text { Social Security paid by } \\
\text { government / GDP }\end{array}$ & $\begin{array}{c}\text { Self employment / } \\
\text { work force }\end{array}$ & $\begin{array}{c}\text { Unemployment } \\
\text { rate }\end{array}$ \\
\hline \multirow{2}{*}{ MIMIC 6-2-1 } & 0.58 & 0.027 & 1.055 & 0.27 & 0.19 & 1.01 \\
& $(0.39)$ & $(0.92)$ & $(0.08)$ & $(0.58)$ & $(0.44)$ & $(0.01)$ \\
\hline \multirow{2}{*}{ MIMIC 6-2-1 } & & & 1.12 & & & 0.88 \\
& & & 0.012 & & $(0.002)$ \\
\hline
\end{tabular}

Most analyzes conclude that the main causes that affect the development of the size of the shadow economy are the tax and social security burden and the intensity of regulations. Taxes affect the choice of work time since the greater the difference between the total cost of labor in the official economy and the after tax earning, the greater the incentive to avoid this difference and to work on shadow economy. An increase in the intensity of regulation, such as trade barriers and labor restrictions for foreigners, reduces the freedom (of choice) for individuals engaged in the official economy and leads to a significant increase in labor costs in the official economy. Since most of these costs can be shifted to employees, there is no further incentive to work in the shadow economy - where they can be avoided.

Unemployment and hours of work by a worker in the formal (official) economy also affect shadow economy. While it is clear that a reduction in working hours in the official economy increase hours worked in the shadow economy, the impact of unemployment in the black economy is unclear.

The inflation rate based on the consumer price index is another variable that we use to measure the shadow economy with the MIMIC model. The inflation the inflation rate based on the consumer price index. First of all, inflation deform the price mechanism by making it difficult to separate varies in relative prices from varies in the general level and creates uncertainty. Consequently, there may be redistribution over where resources and production are cheaper ${ }^{2}$.

So, the inflation rate becomes suspicious the consumer basket of goods and services which the CPI is calculated may not cover enough items that customers have to buy from informal markets ${ }^{3}$. The lower the GDP (officially measured), the fewer are the opportunities for people gain money from the formal economy, and the more they are pushed into the shadow economy. In the short term, we expect this negative relationship to exist. In the longer term, the shadow economy and the official economy complement each other rather than substitute, and so the variables will represent a positive relationship.

Application of the MIMIC model has its shortcomings. (Helberger and Knepel 1988) show that the main conclusions of Frey and WECK - Hannemann are not constant in front of small changes either in the data period or group of countries that are occurring in the study. They also argue that the lists of causal and indicator variables are unpersuasive for the purpose. (Smith 2002) and (Weir and Hill 2002) criticize modeling in Giles and Tedds book, especially the lack of economic theory to guide the specification and complexity of predictive strategy. They also criticize Helberger and Knepel, for the adequacy of cause and indicator variables that are used. Specification and conclusions of Giles and Tedds reviewed in (Breusch 2005), indicate that the time path of their assessment for Canada, has little to do with the Shadow Economy. The model in fact reflects the price, inflation and real growth in the economy. Moreover, their level of assessment is a numerical accident with no connection to the data 4 .

\section{Indicators of the MIMIC Model}

The activities in the Shadow economy affect the activities in the formal economy. They affect the formal sector in manufacturing, capital market and labor market. These factors affect the size of shadow economy in relation to the official economy. In the MIMIC model we use monetary indicators (Y1) (which is the ratio of money close to broad money), formal economic output (Y2) (measured by real GDP) and labor force participation rates (Y3). In terms of monetary

2 JayKaplanhttp://www.colorado.edu/Economics/courses/econ2020/section6/section6-main.html

3 U Myint, "Corruption; Causes, Consequences and Cures", Asia-Pacific Development Journal 7(2) (2000) p.46

${ }^{4} \mathrm{~T}$. Breusch, 'Estimating the Underground Economy using MIMIC Models', School of Economics, Faculty of Economics and Commerce, The Australian National University, (2005), p:2 
indicators, the majority of transactions in the shadow economy is made by cash. However an increase in the shadow economy will increase the demand for cash. In terms of labor force, as the size of the shadow economy grows, the rate of participation in formal labor force will decrease. When labor force in shadow economy grows, the number of people working in the formal economy decreases. Also there will be a decrease in working hours in the formal economy.

In terms of product market, the growth of the shadow economy encourages the movement of inputs from the formal sector to the informal sector. However this situation will reduce productivity in the formal sector that is measured by the official rate of growth. While the production in the Shadow economy increases, this will reflect in the official growth rate. This is because during a recession, inputs, as capital and labor move out of the formal economy, into the shadow economy . So we can say that there is an inverse relationship between the shadow economy and the formal economy. On the other hand, some economists say that is the formal economy that causes the increase of the shadow economy. This happen in economies with a strong linkage between between formal economy and shadow economy. A recession in the growth of the formal economy can lead to a reduction in the growth of the shadow economy. Results indicate the existence of a direct link between the sizes of formal and shadow economy. Schneider and Klingmair found pro - cyclical relation activity between formal (official) and underground (shadow) economy in developed countries, and a countercyclical relation in the developing economies. Although some studies have shown significant findings, they have not been able to give absolute results on the relationship between formal economy and shadow economy.

\section{Conclusion}

Although is difficult to give an exact estimate of relevance of MIMIC for the measurement of the shadow economy, we believe that MIMIC has been useful in calculating the shadow economy and bringing out the variables that have the biggest impact in changing the size of the shadow economy. In some cases the MIMIC model seems to have had some impact on the decision to adopt or reject a particular policy, in other cases such an impact is less clear. Anyway, the MIMIC result have become well known to all kinds of parties participating in the policy arena, simulation result for specifying which concrete policy measures should be implemented, these results make policy makers aware of some important factors to help them to determine the borders of their playing field.

In this paper we demonstrate that the MIMIC model better quantifies the size of the shadow economy. This is particularly advantageous for economists trying to gather more precise figures for and track the development of the shadow economy and, of course, for the improvement of research in this problematical field of statistics. The preciseness of our estimates also benefits policymakers' efforts to deal with the shadow economy and their formulation of economic policy strategies.

\section{References}

Aigner, Dennis, Friedrich Schneider, and Damayanti Ghosh. 1988. "Me and My Shadow: Estimationg the Size of U.S. Hidden Economy from Time Series Data. Dynamic Econometric Modelling. Proceedings of the Third International Symposium in Economic Theory and Econometrics." Cambridge University Press. http://www3.unisi.it/criss/download/meeting2004/papers/dellanno.pdf.

Breusch, Trevor. 2005. "Estimating the Underground Economy Using MIMIC Models." Econometrics (July 25). http://ideas.repec.org /p/wpa/wuwpem/0507003.html.

Çiçek, Deniz, and Ceyhun Elgin. 2011. "Not-Quite-Great Depressions of Turkey: A Quantitative Analysis of Economic Growth over 1968-2004." Economic Modelling 28 (6): 2691-2700. http://ideas.repec.org/a/eee/ecmode/v28y2011i6p2691-2700.html.

D'Erasmo, Pablo N., and Hernan J. Moscoso Boedo. 2012. "Financial Structure, Informality and Development." Journal of Monetary Economics 59 (3) (April): 286-302. doi:10.1016/j.jmoneco.2012.03.003. http://www.sciencedirect.com/science/article/pii/ S0304393212000372.

Dell'Anno, Roberto, and Friedrich Schneider. 2004. "The Shadow Economy of Italy and Other OECD Countries: What Do We Know?" http://www.progettoitaliafederale.it/docs/ForthcomingPFPC_final_version_08_07.pdf.

Dreher, Axel, and Friedrich Schneider. 2010. "Corruption and the Shadow E-conomy: An Empirical Analysis." Public Choice. doi:10.1007/s11127-009-9513-0.

Elgin, Ceyhun. 2012. "Internet Usage and the Shadow Economy: Evidence from Panel Data." Working Papers. http://ideas. repec.org/p/bou/wpaper/2012-09.html.

Feige, Edgar L. 1990. "Defining and Estimating Underground and Informal Economies: The New Institutional Economics Approach." World Development. doi:10.1016/0305-750X(90)90081-8.

Fleming, Matthew H., John Roman, and Graham Farrell. 2000. "The Shadow Economy." Journal of International Affairs 53 (2) (March 22): 387. http://www.questia.com/library/journal/1G1-62361345/the-shadow-economy.

Frey, Bruno S, and Hannelore Weck-Hanneman. 1984. "The Hidden Economy as an 'unobserved' Variable." European Economic Review. doi:10.1016/0014-2921(84)90020-5. 
Frey, Bruno S., and Werner W. Pommerehne. 1984. "The Hidden Economy: State and Prospects for Measurment." http://www.roiw.org 11984/1.pdf.

Giles, David E A. 1999. "MODELLING THE HIDDEN ECONOMY AND THE TAX-GAP IN NEW ZEALAND" (February).

Goldberger, Arthur S. 1972. "Maximum-Likelihood Estimation of Regressions Containing Unobservable Independent Variables." International Economic Review 13 (1): 1-15. http://ideas.repec.org/a/ier/iecrev/v13y1972i1p1-15.html.

Hart, Keith. 2008. "Informal Economy, The New Palgrave Dictgionary of Economics. Second Edition."

Hatipoglu, Ozan, and Gulenay Ozbek. 2011. "On the Political Economy of the Informal Sector and Income Redistribution." European Journal of Law and Economics 32 (1): 69-87. http://ideas.repec.org/a/kap/ejlwec/v32y2011i1p69-87.html.

Helberger, Christof, and Helmut Knepel. 1988. "How Big Is the Shadow Economy?: A Re-Analysis of the Unobserved-Variable Approach of B.S. Frey and H. Weck-Hannemann." European Economic Review 32: 965-976. doi:10.1016/0014-2921(88)90055-4. http://www.sciencedirect.com/science/article/pii/0014292188900554.

Ihrig, Jane, and Karine S. Moe. 2004. "Lurking in the Shadows: The Informal Sector and Government Policy." Journal of Development Economics 73 (2): 541-557. http://ideas.repec.org/a/eee/deveco/v73y2004i2p541-557.html.

Johnson, Simon, Daniel Kaufmann, and Andrei Shleifer. 1997. "Politics and Entrepreneurship in Transition Economies." William Davidson Institute Working Papers Series (June 1). http://ideas.repec.org/p/wdi/papers/1997-57.html.

Johnson, Simon, Daniel Kaufmann, and Pablo Zoido-Lobaton. 1998. "Regulatory Discretion and the Unofficial Economy." American Economic Review 88 (2): 387-92. http://ideas.repec.org/a/aea/aecrev/v88y1998i2p387-92.html.

Loayza, Norman V. 1996. "The Economics of the Informal Sector: A Simple Model and Some Empirical Evidence from Latin America." Carnegie-Rochester Conference Series on Public Policy 45 (1): 129-162. http://ideas.repec.org/a/eee/crcspp/v45y1996ip129162.html.

Orsi, R., D. Raggi, and F. Turino. 2012. "Size, Trend, and Policy Implications of the Underground Economy." Working Papers. http://ideas.repec.org/p/bol/bodewp/wp818.html.

Schneider, F, and R Dell'Anno. 2003. "The Shadow Economy of Italy and Other OECD Countries: What Do We Know ?" Journal of Public Finance and Public Choice Economia Delle Scelte Pubbliche 21: 97-120. http://dialnet.unirioja.es/servlet/ articulo?codigo $=1442209$.

Schneider, Friedrich. 2005. "Shadow Economies around the World: What Do We Really Know?" European Journal of Political Economy. doi:10.1016/j.ejpoleco.2004.10.002.

Schneider, Friedrich, and Dominik H Enste. 2000. "Shadow Economies: Size, Causes, and Consequences." Journal of Economic Literature. doi:10.1257/jel.38.1.77.

Schneider, Friedrich G., and Dominik H. Enste. 2002. "The Shadow Economy: Theoretical Approaches, Empirical Studies, and Political Implications." http://www.economics-ejournal.org/economics/journalarticles/2007-9/version_1.

Smith, Mark. K. 2002. "Malcolm Knowles, Informal Adult Education, Self-Direction and Andragogy." http://infed.org/mobi/malcolmknowles-informal-adult-education-self-direction-and-andragogy/.

Tanzi, Vito. 1983. "The Underground Economy in the United States: Annual Estimates, 1930-80 (L'Ã@conomie Clandestine Aux EtatsUnis: Estimations Annuelles, 1930-80) (La 'economÃa subterrÃjnea' de Estados Unidos: Estimaciones Anuales, 1930-80)." IMF Staff Papers 30 (2): 283-305. http://ideas.repec.org/a/pal/imfstp/v30y1983i2p283-305.html.

Weir, B S, and W G Hill. 2002. "Estimating F-Statistics." Annual Review of Genetics 36: 721-750. doi:10.1146/annurev.genet. 36.050802.093940.

Zellner, Arnold. 1970. "Estimation of Regression Relationships Containing Unobservable Independent Variables." International Economic Review 11 (3): 441-54. http://ideas.repec.org/a/ier/iecrev/v11y1970i3p441-54.html. 